\title{
Potential Role of Serine Proteases in Modulating Renal Sodium Transport in vivo
}

\author{
G. Jacquillet $^{a} \quad$ I. Ruberab R.J. Unwin $^{a}$ \\ a UCL Centre for Nephrology, Royal Free Hospital, University College London, London, UK; b TIANP, CNRS-UMR 6097, \\ Université de Nice Sophia Antipolis, Nice, France
}

\section{Key Words}

Kidney $\cdot$ Renal tubule $\cdot$ Sodium $\cdot$ Protease $\cdot$ Epithelial sodium channel $\cdot$ Protease-activated receptor

\begin{abstract}
The maintenance of sodium $\left(\mathrm{Na}^{+}\right)$homeostasis is an essential function of the kidney. It is achieved by a variety of transport processes localized all along the highly specialised segments of the nephron. Impairment of these transport mechanisms, and thereby $\mathrm{Na}^{+}$handling, is associated with disturbed $\mathrm{Na}^{+}$and water balance, leading to hypertension and oedema. This review focuses on the novel regulation of sodium reabsorption by serine proteases acting along the entire nephron.

Copyright $\odot 2011$ S. Karger AG, Basel
\end{abstract}

\section{Sodium ( $\mathrm{Na}^{+}$) Transport and Its Regulation along the Nephron}

Sodium reabsorption occurs throughout the length of the nephron (fig. 1) via both paracellular (between the cells) and transcellular (across cells) pathways (fig. 2-4). Transcellular $\mathrm{Na}^{+}$entry across the apical membrane is carried out by sodium transporters (cotransporters, exchangers, and ion channels) expressed in each nephron segment; $\mathrm{Na}^{+}$extrusion is achieved across the basolateral membrane by the $\mathrm{Na}^{+}, \mathrm{K}^{+}$-ATPase pump present along the entire nephron. Sodium uptake is mediated predominantly by the $\mathrm{Na}^{+}-\mathrm{H}^{+}$exchanger NHE3 in the proximal tubule (fig. 2), by the $\mathrm{Na}^{+}, \mathrm{K}^{+}-2 \mathrm{Cl}^{-}$cotransporter NKCC2 in the thick ascending limb (TAL) of Henle's loop (fig. 3), and by the thiazide-sensitive $\mathrm{Na}^{+}-\mathrm{Cl}^{-}$cotransporter NCC in the distal convoluted tubule. The connecting tubule and collecting duct play an important role in the fine regulation of $\mathrm{Na}^{+}$handling. In principal cells, $\mathrm{Na}^{+}$reabsorption is mediated by a selective and amiloride-sensitive electrogenic epithelial ion channel, ENaC (fig. 4). Also, recently in the collecting duct intercalated cells an ENaCindependent, thiazide-sensitive, electroneutral $\mathrm{Na}^{+}$reabsorptive mechanism has been described, suggesting a parallel action of $\mathrm{Na}^{+}$-dependent $\mathrm{Cl}^{-} / \mathrm{HCO}_{3}{ }^{-}$exchange (NDCBE/SLC4A8) with $\mathrm{Na}^{+}$-independent $\mathrm{Cl}^{-} / \mathrm{HCO}_{3}{ }^{-}$ exchange (pendrin/SLC26A4) (fig. 4) [1].

The importance of $\mathrm{Na}^{+}$transporting proteins in the control of $\mathrm{Na}^{+}$balance and blood pressure is clearly demonstrated by genetic disorders of NKCC2 (Bartter's syndrome) and NCC (Gitelman's syndrome), in which loss of function mutations in these genes is associated with in-

\section{KARGER}

Fax +4161306 1234 E-Mail karger@karger.ch www.karger.com
(C) 2011 S. Karger AG, Basel

$1660-2137 / 11 / 1192-0022 \$ 38.00 / 0$

Accessible online at:

www.karger.com/nep
Dr. Grégory Jacquillet

UCL Centre for Nephrology, UCL Medical School

London NW3 2PF (UK)

E-Mail g.jacquillet@medsch.ucl.ac.uk 


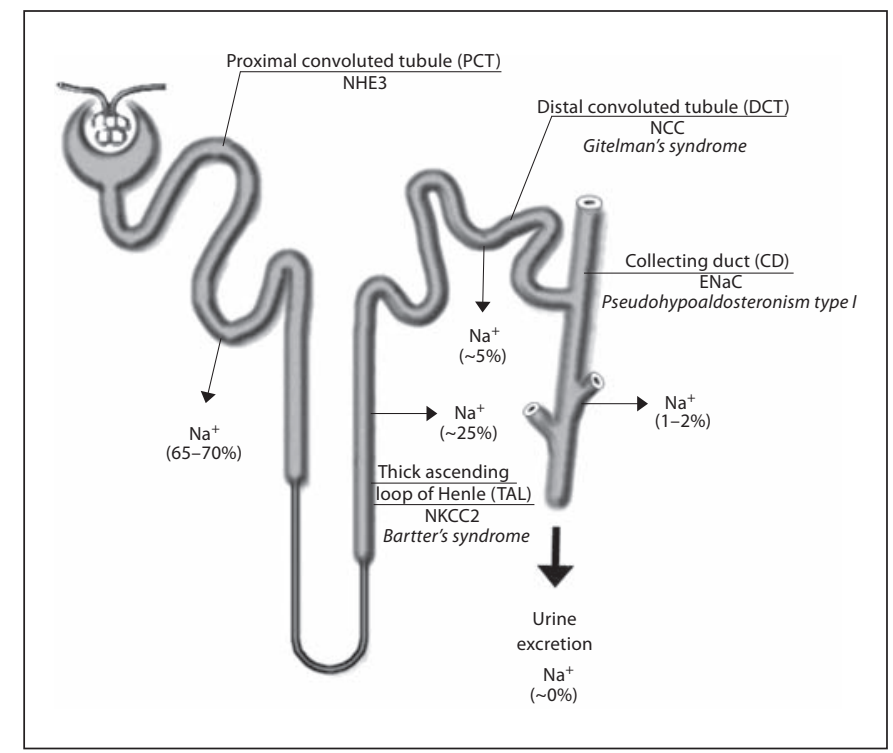

Fig. 1. Sodium reabsorption along the nephron.

creased renal $\mathrm{Na}^{+}$losses and a low blood pressure, and mutations of $E N a C$, where loss of function also causes increased $\mathrm{Na}^{+}$wasting and a low blood pressure (pseudohypoaldosteronism type 1a, PHA-1), and gain of function the opposite with hypertension (Liddle's syndrome) (fig. 1).

Apical $\mathrm{Na}^{+}$entry is limiting for transepithelial $\mathrm{Na}^{+}$ transport; it is regulated by various factors (hormones, and intra- and extracellular non-hormonal signalling factors) acting on $\mathrm{Na}^{+}$transporters at several levels: mRNA and protein synthesis, protein degradation, intracellular protein trafficking, its surface expression, and its activity. For example, the steroid hormone aldosterone increases the activity of NCC and ENaC in the aldosterone-sensitive distal nephron via induction of serumand glucocorticoid-inducible kinase, SGK1 $[2,3]$. The action of SGK1 on ENaC appears to be mediated through a Nedd4-2 (Neural precursor cell-expressed, developmentally down-regulated 4-2)-dependent mechanism. SGK1 phosphorylates and sequesters the E3 ubiquitin ligase Nedd4-2, which promotes ubiquitination-dependent targeting of $\mathrm{ENaC}$ for endocytosis at the plasma membrane and intracellular degradation [4]. WNK (with no lysine) kinases comprise a regulatory system that controls several $\mathrm{Na}^{+}$transport proteins (NKCC2, NCC, ENaC). For example, aldosterone-induced SGK1 phosphorylates WNK4 and inactivates the inhibitory effects of WNK4 on NCC, resulting in enhanced $\mathrm{Na}^{+}$reabsorption in dis- tal tubular cells [3]; in collecting duct cells, WNK1 and WNK4 stimulate SGK1 leading to activation of ENaC [5]. The action of SGK1 on ENaC can also be mediated by a Nedd4-2-independent mechanism: Diakov and Korbmacher [6] have demonstrated a novel pathway of ENaC activation by SGK1 involving phosphorylation of a serine residue of its $\mathrm{C}$ terminus. This finding suggests that SGK1 may directly contribute to aldosterone-induced activation of ENaC channels already present in the plasma membrane.

Other novel mechanisms influencing $\mathrm{Na}^{+}$transport include the serine proteases. This review focuses on $\mathrm{Na}^{+}$ transport regulation along the nephron by serine proteases. Serine protease regulation of $\mathrm{Na}^{+}$reabsorption can be achieved by direct cleavage of a $\mathrm{Na}^{+}$transporting protein (e.g. ENaC in the cortical collecting duct, CCD) or through an interaction with protease-activated receptors (e.g. PAR-2 in the TAL), or by modulating paracellular permeability.

\section{Serine Proteases in the Kidney}

Serine proteases are proteolytic enzymes present in viruses, bacteria and eukaryotes, and they are involved in the regulation of several physiological processes, including blood coagulation, digestion, and inflammation [7]. They are characterized by a catalytic triad motif composed of serine, histidine and aspartate residues that are required for enzymatic activity. Serine proteases are classified and grouped on the basis of their structural and functional similarities (MEROPS database, http:// merops.sanger.ac.uk). In the kidney, serine proteases can act intracellularly, such as the ubiquitously expressed furin, or extracellularly. The membrane-bound serine proteases are anchored either via a carboxy-terminal transmembrane domain (type I), a carboxy-terminal hydrophobic region that functions as a signal for membrane attachment via a glycosyl-phosphatidylinositol linkage (GPI-anchored), or via an amino-terminal transmembrane domain (type II).

Serine proteases such as plasmin and secreted CAP1 (channel-activating protease), and kallikrein are also present in urine [8-10]. In the kidney, the GPI-anchored serine protease CAP1 is expressed in the proximal tubule, the cortical TAL and the CCD [11]. The type II transmembrane serine protease CAP 3 is expressed at the basolateral plasma membrane of ductal epithelial cells of the kidney mainly in the distal collecting ducts more than in the proximal collecting ducts [12], and the serine 
Fig. 2. Proximal convoluted tubule sodium transport.



Fig. 3. TAL of Henle's loop sodium transport.




Fig. 4. Collecting duct sodium transport.



exopeptidase dipeptidyl-peptidase IV (DPPIV; CD26), which degrades the insulin-stimulating hormone glucagon-like peptide-1 (GLP-1), is one of the major brush-border membrane proteins of the proximal tubules [13].

\section{Effect of Serine Proteases on $\mathrm{Na}^{+}$Transporting Proteins of the Brush Border Membrane of the Proximal Tubule (see fig. 2)}

Only a few studies have described the interaction of proteases with $\mathrm{Na}^{+}$transport along the proximal tubule. In 1992, Sabolic et al. [14] showed that, when applied externally, several proteases can cause significant inhibition of NHE3 in apical brush border membrane (BBM) vesicles prepared from rat renal cortex, although not trypsin. However, when applied to the cytoplasmic membrane surface, trypsin activated NHE3 in BBM vesicles prepared from rabbit renal cortex by cleaving an inhibitory site on the exchanger corresponding to the PKA regulatory binding site [15].

A key aspect of the regulation by proteases of $\mathrm{Na}^{+}$ transport in the proximal tubule seems to be an association between DPPIV and NHE3. DPPIV is a plasma membrane anchored ecto-protease also known as the leukocyte antigen CD26; it is expressed in a variety of epithelial and non-epithelial cells [16]. The kidney is a main site of expression of DPPIV, where it constitutes up to $14 \%$ of total membrane protein [17]. It is a highly specific serine protease with catalytic activity, but it can also 
function as a binding protein $[18,19]$. When associated with NHE3, the resulting oligomeric complex is exclusively distributed in microvilli of the BBM of the proximal tubule, where NHE3 is also active [13]. Conversely, when NHE3 is associated with megalin in intermicrovillar coated pits it is inactive [13]. The association with DPPIV seems to regulate directly or indirectly NHE3 activity by controlling its surface expression and/or activity. Girardi et al. [20] have shown that inhibition of DPPIV catalytic activity in the proximal tubule of rats in vivo inhibits NHE3 activity by redistributing the exchanger from microvillar membranes to the intermicrovillar microdomain of the brush border.

\section{Modulation of $\mathrm{Na}^{+}$Transport by Serine Protease-Induced Proteolysis of $\mathrm{Na}^{+}$Transporting Proteins (see fig. 4)}

Serine protease regulation of $\mathrm{Na}^{+}$transport implicates cleavage of $\mathrm{Na}^{+}$transporting proteins. Proteolytic activation of the $\mathrm{Na}^{+}$channel $\mathrm{ENaC}$ in the aldosterone-sensitive distal nephron has a key role in optimising channel activity (Po, open probability). ENaC is composed of three homologous subunits $\alpha, \beta$ and $\gamma$. Each subunit has short cytosolic N- and C-terminal domains, two transmembrane domains separated by a large extracellular region, which is the target for proteolysis.

\section{Furin}

Furin is a proprotein convertase that resides mainly in the trans-Golgi network, where it processes target proteins passing through the biosynthetic pathway, including $\mathrm{ENaC}$. Furin cleaves the $\alpha \mathrm{ENaC}$ subunit at two sites in the extracellular domain, releasing a 26-residue inhibitory fragment, resulting in $\mathrm{ENaC}$ channel activation [21]. However, furin cleaves the $\gamma$-subunit in the ectodomain at a single site only [22], whereas full activation of the channel requires the release of a second inhibitory domain from the $\gamma$-subunit, indicating that a second distal cleavage of the $\gamma$-subunit is produced by other serine proteases (e.g. CAP1, kallikrein or plasmin).

\section{CAP1/Prostasin}

CAP1, a GPI-anchored serine protease, also called prostasin, is encoded by Prss 8 gene (protease serine S1 family member 8 ). CAP1 is the first 'channel-activating protease' isolated from a mouse cortical collecting duct cell line [11] and activates ENaC in the Xenopus oocyte expression system [11], and in cortical collecting duct cell lines $[8,23]$, by modulating channel gating; silencing of the CAP1/prostasin gene reduced sodium transport in a cortical collecting duct cell line [23]. Mechanisms by which CAP1 affects ENaC activity are complex. Bruns et al. [22] have identified a CAP1 cleavage site in the $\gamma$-subunit of $\mathrm{ENaC}$ at a tetrabasic site distal to the furin cleavage site. Cleavage of the $\gamma$-subunit by furin and CAP1 release a 43 -residue inhibitory peptide, leading to full activation of the ENaC channel [22].

\section{$C A P 2$ and $C A P 3$}

CAP2 (TMPRSS4) and CAP3 (matriptase), the gene products of Prss4 and Prss14, respectively, are type II transmembrane serine proteases originally isolated from a mouse cortical collecting duct cell line. Both increase $\mathrm{ENaC}$ activity by enhancing channel open probability in the Xenopus oocyte expression system [24]. CAP2 has been shown to activate $\mathrm{ENaC}$ by cleaving the $\gamma$-subunit of rat $\mathrm{ENaC}$ at position $\mathrm{R} 138$, a site distal to the furin site [25]. In intestinal Caco-2 cells, Friis et al. [26] have shown a new basolateral prostasin activation process. Even if prostasin is mainly located on the apical plasma membrane, a small fraction can be found on the basolateral plasma membrane co-localizing with matriptase. Basolateral prostasin can be activated by matriptase, endocytosed and transcytosed to the apical plasma membrane, where it accumulates.

\section{Plasmin}

The serine protease plasmin has also been shown to directly cleave and activate $\mathrm{ENaC}$; extracellular plasmin application cleaves the $\gamma$-subunit of $\mathrm{ENaC}$ at a site distal to the furin site and activates $\mathrm{Na}^{+}$currents in Xenopus oocytes [9]. In a mouse cortical collecting duct cell line, Svenningsen et al. [27] demonstrated that at high concentrations plasmin directly activates $\mathrm{ENaC}$, while at low concentrations plasmin interacts with CAP1, leading to $\gamma$-subunit cleavage. Nephrotic urine from human and rats activates $\mathrm{ENaC}$ currents in mouse collecting duct cells, and plasmin was identified by mass spectrometry as the dominant serine protease responsible for this effect [28].

\section{Kallikrein}

Tissue kallikrein (TK) is a serine protease synthesized in the renal connecting tubule cells and secreted into the tubular fluid at late distal nephron segments. In isolated mouse cortical collecting ducts microperfused in vitro, luminal TK was shown to activate ENaC [10]. Studies with TK knockout mice suggest that TK may activate 
$\mathrm{ENaC}$ by cleavage of its $\gamma$-subunit in the kidney [10]. Besides TK's potential role in $\mathrm{Na}^{+}$homeostasis, it has also been reported to control acid-base and potassium transport in CCD intercalated cells by directly inhibiting $\mathrm{HCO}_{3}{ }^{-} / \mathrm{Cl}^{-}$exchange [29] and (colonic) $\mathrm{H}^{+} / \mathrm{K}^{+}$ATPase, respectively [30].

\section{Serine Protease Modulation of $\mathrm{Na}^{+}$Homeostasis through Cleavage of Protease-Activated Receptors (see fig. 3)}

Another way in which serine proteases may regulate $\mathrm{Na}^{+}$transport is to act on protease-activated receptors (PARs). PARs are a family of G-protein-coupled receptors with four members (PAR-1-4). Specific serine proteases cleave PARs within the extracellular domain to expose a tethered ligand domain that binds and activates the cleaved receptors, initiating an intracellular signalling cascade [31]. PAR-2 is expressed in the renal cortex [32]. In vivo, in normal conditions, it is mainly located within the blood vessel wall, whereas in IgA nephropathy there is a considerable increase in PAR-2 protein expression, particularly at the level of the proximal tubule [33]. In vitro, PAR-2 can also be found at the basolateral membrane of the isolated cortical TAL and in cultured collecting duct cells [31,34]. Several serine proteases regulate PAR2, such as trypsin, kallikrein, and elastase [31]. PAR-2activated $\mathrm{Na}^{+}$transport by serine protease has been described in cortical TAL microperfused in vitro through regulation of $\mathrm{Na}^{+}, \mathrm{K}^{+}$-ATPase [34].

\section{Serine Protease Modulation of Sodium Homeostasis through Paracellular Permeability Regulation (see fig. 3, 4)}

In addition to modulating transcellular $\mathrm{Na}^{+}$transport in the kidney, serine proteases have also been reported to regulate paracellular permeability. The tight junctions constitute the main barrier in epithelia to the passive movement of electrolytes and macromolecules via the paracellular pathway. In mouse CCD cells, prostasin has been shown to be an important regulator of tight junction paracellular permeability $[35,36]$, and it is more likely that prostasin is required for the development of transepithelial electrical resistance in renal collecting duct epithelium [37]. Moreover, PAR-2 activation has been shown to increase paracellular permeability to $\mathrm{Na}^{+}$in rat cortical TAL microperfused in vitro [34]. Furthermore, a link between serine proteases and tight junction structure has been described in other tissues: a model of skinspecific CAP1/Prss8-deficient mouse exhibited impaired function of tight junctions [38], and genetic deletion of matriptase in the intestine was associated with an increased paracellular permeability through an effect on claudin-2 expression [39].

\section{Serine Proteases in $\mathrm{Na}^{+}$Homeostasis in vivo and in Disease}

The question arises whether protease-mediated $\mathrm{Na}^{+}$ transport in the kidney is physiologically or pathologically relevant and important in vivo. Changes in renal serine protease activity might disturb $\mathrm{Na}^{+}$balance and therefore blood pressure control. Indeed, altered serine protease levels in human urine, such urinary kallikrein $[40,41]$, CAP1/prostasin [8, 42], and plasmin [28], have been associated with hypertension and kidney diseases with disturbed $\mathrm{Na}^{+}$and water balance like the nephrotic syndrome.

In vivo studies in rats have shown that increasing the levels of aldosterone (by a salt-restricted diet or by aldosterone infusion), an important regulator of $\mathrm{Na}^{+}$reabsorption, stimulated urinary excretion of CAP1/prostasin, and induced hypertension [8]. Urinary kallikrein excretion has also been reported to be increased by aldosterone increase and decreased following adrenalectomy in rats [43]. Moreover, aldosterone stimulation in rats increased expression of proteolytic fragments of $\alpha \mathrm{ENaC}$ and $\gamma \mathrm{ENaC}$ subunits in kidneys, corresponding, presumably, to cleavage of the $\alpha$ subunit by furin and the $\gamma$-subunit by both furin and a second serine protease [44-46].

Plasmin is present in the urine of patients with the nephrotic syndrome, but not under normal conditions [28]. In proteinuric disease, plasminogen crosses the glomerular filtration barrier and can be converted to plasmin by tubular fluid urokinase. Plasmin-induced activation of $\mathrm{ENaC}$ may contribute to $\mathrm{Na}^{+}$retention, extracellular volume expansion and hypertension, all of which can be observed in the nephrotic syndrome.

Recently, Maekawa et al. [23] have shown that camostat mesilate, a synthetic serine protease inhibitor, directly inhibited CAP1/prostasin activity and decreased $\mathrm{Na}^{+}$ transport in a cortical collecting duct cell line in vitro; oral administration of camostat mesilate to Dahl saltsensitive rats fed a high salt diet, a model of salt-sensitive hypertension, decreased blood pressure and renal injury [23]. 


\section{Conclusions}

The evidence that serine proteases can activate $\mathrm{ENaC}$ is clear-cut, but whether this occurs to any significant extent in vivo is still not known. Moreover, how the production, release and control of these enzymes occur is also unknown. Further studies addressing the role of these proteases in $\mathrm{Na}^{+}$homeostasis in vivo and at different nephron sites is necessary to determine their physiological relevance, but then also what physiological or pathological factors can affect their synthesis, release and activity.

\section{Acknowledgment}

G.J. is grateful to the European Renal Association (ERA/ EDTA) for fellowship support.

\section{References}

1 Leviel F, Hubner CA, Houillier P, Morla L, El Moghrabi S, Brideau G, Hatim H, Parker MD, Kurth I, Kougioumtzes A, Sinning A, Pech V, Riemondy KA, Miller RL, Hummler E, Shull GE, Aronson PS, Doucet A, Wall $\mathrm{SM}$, Chambrey R, Eladari D: The $\mathrm{Na}^{+}-\mathrm{de}-$ pendent chloride-bicarbonate exchanger SLC4A8 mediates an electroneutral $\mathrm{Na}^{+}$reabsorption process in the renal cortical collecting ducts of mice. J Clin Invest 2010;120: 1627-1635.

-2 Naray-Fejes-Toth A, Helms MN, Stokes JB, Fejes-Toth G: Regulation of sodium transport in mammalian collecting duct cells by aldosterone-induced kinase, SGK1: structure/function studies. Mol Cell Endocrinol 2004;217:197-202.

-3 Rozansky DJ, Cornwall T, Subramanya AR, Rogers S, Yang YF, David LL, Zhu X, Yang CL, Ellison DH: Aldosterone mediates activation of the thiazide-sensitive $\mathrm{Na}-\mathrm{Cl}$ cotransporter through an SGK1 and WNK4 signaling pathway. J Clin Invest 2009;119: 2601-2612.

4 Debonneville C, Flores SY, Kamynina E, Plant PJ, Tauxe C, Thomas MA, Munster C, Chraibi A, Pratt JH, Horisberger JD, Pearce D, Loffing J, Staub O: Phosphorylation of Nedd4-2 by Sgk1 regulates epithelial $\mathrm{Na}^{+}$ channel cell surface expression. EMBO J 2001;20:7052-7059.

-5 Heise CJ, Xu BE, Deaton SL, Cha SK, Cheng CJ, Earnest S, Sengupta S, Juang YC, Stippec $\mathrm{S}, \mathrm{Xu}$ Y, Zhao Y, Huang CL, Cobb MH: Serum and glucocorticoid-induced kinase (SGK)- 1 and the epithelial sodium channel are regulated by multiple with no lysine (WNK) family members. J Biol Chem 2010; 285:25161-25167.

-6 Diakov A, Korbmacher C: A novel pathway of epithelial sodium channel activation involves a serum- and glucocorticoid-inducible kinase consensus motif in the $\mathrm{C}$ terminus of the channel's $\alpha$-subunit. J Biol Chem 2004;279:38134-38142.
7 Neurath H: Proteolytic enzymes, past and future. Proc Natl Acad Sci USA 1999;96: 10962-10963.

8 Narikiyo T, Kitamura K, Adachi M, Miyoshi T, Iwashita K, Shiraishi N, Nonoguchi H, Chen LM, Chai KX, Chao J, Tomita K: Regulation of prostasin by aldosterone in the kidney. J Clin Invest 2002;109:401-408.

-9 Passero CJ, Mueller GM, Rondon-Berrios H, Tofovic SP, Hughey RP, Kleyman TR: Plasmin activates epithelial $\mathrm{Na}^{+}$channels by cleaving the $\gamma$-subunit. J Biol Chem 2008; 283:36586-36591.

10 Picard N, Eladari D, El Moghrabi S, Planes C, Bourgeois S, Houillier P, Wang Q, Burnier M, Deschenes G, Knepper MA, Meneton P, Chambrey R: Defective ENaC processing and function in tissue kallikrein-deficient mice. J Biol Chem 2008;283:4602-4611.

11 Vuagniaux G, Vallet V, Jaeger NF, Pfister C, Bens M, Farman N, Courtois-Coutry N, Vandewalle A, Rossier BC, Hummler E: Activation of the amiloride-sensitive epithelial sodium channel by the serine protease mCAP1 expressed in a mouse cortical collecting duct cell line. J Am Soc Nephrol 2000; 11:828-834.

12 Wang JK, Lee MS, Tseng IC, Chou FP, Chen YW, Fulton A, Lee HS, Chen CJ, Johnson MD, Lin CY: Polarized epithelial cells secrete matriptase as a consequence of zymogen activation and HAI-1-mediated inhibition. Am J Physiol Cell Physiol 2009;297:C459-C470.

13 Girardi AC, Degray BC, Nagy T, Biemesderfer D, Aronson PS: Association of $\mathrm{Na}^{+}-\mathrm{H}^{+} \mathrm{ex}-$ changer isoform NHE3 and dipeptidyl peptidase IV in the renal proximal tubule. J Biol Chem 2001;276:46671-46677.

14 Sabolic I, Shi LB, Brown D, Ausiello DA, Verkman AS: Proteinases inhibit $\mathrm{H}^{+}$-ATPase and $\mathrm{Na}^{+} / \mathrm{H}^{+}$exchange but not water transport in apical and endosomal membranes from rat proximal tubule. Biochim Biophys Acta 1992;1103:137-147.

15 Weinman EJ, Dubinsky WP, Dinh Q, Steplock D, Shenolikar S: Effect of limited trypsin digestion on the renal $\mathrm{Na}^{+}-\mathrm{H}^{+}$exchanger and its regulation by cAMP-dependent protein kinase. J Membr Biol 1989;109:233-241.
16 Augustyns K, Bal G, Thonus G, Belyaev A, Zhang XM, Bollaert W, Lambeir AM, Durinx C, Goossens F, Haemers A: The unique properties of dipeptidyl-peptidase IV (DPP IV/CD26) and the therapeutic potential of DPP IV inhibitors. Curr Med Chem 1999;6: 311-327.

17 Sedo A, Duke-Cohan JS, Balaziova E, Sedova LR: Dipeptidyl peptidase IV activity and/or structure homologs: contributing factors in the pathogenesis of rheumatoid arthritis? Arthritis Res Ther 2005;7:253-269.

18 Antonyan AA, Sharoyan SG, Mardanyan SS, Galoyan AA: Proline-rich cytokine from neurosecretory granules: a new natural substrate for dipeptidyl peptidase IV. Neurochem Res 2011;36:34-38.

19 Reinhold D, Kahne T, Steinbrecher A, Wrenger S, Neubert K, Ansorge S, Brocke S: The role of dipeptidyl peptidase IV enzymatic activity in T-cell activation and autoimmunity. Biol Chem 2002;383:1133-1138.

20 Girardi AC, Fukuda LE, Rossoni LV, Malnic G, Reboucas NA: Dipeptidyl peptidase IV inhibition downregulates $\mathrm{Na}^{+}-\mathrm{H}^{+}$exchanger NHE3 in rat renal proximal tubule. Am J Physiol Renal Physiol 2008;294:F414-F422.

21 Carattino MD, Sheng S, Bruns JB, Pilewski JM, Hughey RP, Kleyman TR: The epithelial $\mathrm{Na}^{+}$channel is inhibited by a peptide derived from proteolytic processing of its $\alpha$-subunit. J Biol Chem 2006;281:18901-18907.

$\checkmark 22$ Bruns JB, Carattino MD, Sheng S, Maarouf AB, Weisz OA, Pilewski JM, Hughey RP, Kleyman TR: Epithelial $\mathrm{Na}^{+}$channels are fully activated by furin- and prostasin-dependent release of an inhibitory peptide from the $\gamma$-subunit. J Biol Chem 2007;282: 6153-6160.

23 Maekawa A, Kakizoe Y, Miyoshi T, Wakida N, Ko T, Shiraishi N, Adachi M, Tomita K, Kitamura K: Camostat mesilate inhibits prostasin activity and reduces blood pressure and renal injury in salt-sensitive hypertension. J Hypertens 2009;27:181-189. 
-24 Vuagniaux G, Vallet V, Jaeger NF, Hummler E, Rossier BC: Synergistic activation of $\mathrm{ENaC}$ by three membrane-bound channel-activating serine proteases (mCAP1, mCAP2, and mCAP3) and serum- and glucocorticoid-regulated kinase (Sgk1) in Xenopus oocytes. J Gen Physiol 2002;120:191-201.

-25 Garcia-Caballero A, Dang Y, He H, Stutts MJ: ENaC proteolytic regulation by channelactivating protease 2. J Gen Physiol 2008; 132:521-535.

-26 Friis S, Godiksen S, Bornholdt J, Selzer-Plon J, Rasmussen HB, Bugge TH, Lin CY, Vogel LK: Transport via the transcytotic pathway makes prostasin available as a substrate for matriptase. J Biol Chem 2011;286:57935802.

-27 Svenningsen P, Uhrenholt TR, Palarasah Y, Skjodt K, Jensen BL, Skott O: Prostasin-dependent activation of epithelial $\mathrm{Na}^{+}$channels by low plasmin concentrations. Am J Physiol Regul Integr Comp Physiol 2009;297:R1733R1741.

-28 Svenningsen P, Bistrup C, Friis UG, Bertog M, Haerteis S, Krueger B, Stubbe J, Jensen ON, Thiesson HC, Uhrenholt TR, Jespersen B, Jensen BL, Korbmacher C, Skott O: Plasmin in nephrotic urine activates the epithelial sodium channel. J Am Soc Nephrol 2009; 20:299-310.

-29 Valles P, Ebner S, Manucha W, Gutierrez L, Marin-Grez M: Effect of glandular kallikrein on distal nephron $\mathrm{HCO}_{3}{ }^{-}$secretion in rats and on $\mathrm{HCO}_{3}{ }^{-}$secretion in MDCK cells. Am J Physiol 1997;273:F807-F816.

-30 El Moghrabi S, Houillier P, Picard N, Sohet F, Wootla B, Bloch-Faure M, Leviel F, Cheval L, Frische S, Meneton P, Eladari D, Chambrey R: Tissue kallikrein permits early renal adaptation to potassium load. Proc Natl Acad Sci USA 2010;107:13526-13531.
31 Vesey DA, Hooper JD, Gobe GC, Johnson DW: Potential physiological and pathophysiological roles for protease-activated receptor-2 in the kidney. Nephrology (Carlton) 2007;12:36-43.

32 Bertog M, Letz B, Kong W, Steinhoff M, Higgins MA, Bielfeld-Ackermann A, Fromter E, Bunnett NW, Korbmacher C: Basolateral proteinase-activated receptor (PAR-2) induces chloride secretion in M-1 mouse renal cortical collecting duct cells. J Physiol 1999; 521:3-17.

33 Grandaliano G, Pontrelli P, Cerullo G, Monno R, Ranieri E, Ursi M, Loverre A, Gesualdo L, Schena FP: Protease-activated receptor-2 expression in IgA nephropathy: a potential role in the pathogenesis of interstitial fibrosis. J Am Soc Nephrol 2003;14:2072-2083.

34 Morla L, Crambert G, Mordasini D, Favre G Doucet A, Imbert-Teboul M: Proteinase-activated receptor 2 stimulates $\mathrm{Na}, \mathrm{K}$-ATPase and sodium reabsorption in native kidney epithelium. J Biol Chem 2008;283:2802028028.

35 Liu L, Hering-Smith KS, Schiro FR, Hamm LL: Serine protease activity in m-1 cortical collecting duct cells. Hypertension 2002;39: 860-864.

36 Verghese GM, Gutknecht MF, Caughey GH: Prostasin regulates epithelial monolayer function: cell-specific Gpld1-mediated secretion and functional role for GPI anchor Am J Physiol Cell Physiol 2006;291:C1258C1270.

37 Steensgaard M, Svenningsen P, Tinning AR, Nielsen TD, Jorgensen F, Kjaersgaard G, Madsen K, Jensen BL: Apical serine protease activity is necessary for assembly of a highresistance renal collecting duct epithelium. Acta Physiol (Oxf) 2010;200:347-359.

38 Leyvraz C, Charles RP, Rubera I, Guitard M, Rotman S, Breiden B, Sandhoff K, Hummler E: The epidermal barrier function is dependent on the serine protease CAP1/Prss8. J Cell Biol 2005;170:487-496.
39 Buzza MS, Netzel-Arnett S, Shea-Donohue T, Zhao A, Lin CY, List K, Szabo R, Fasano A, Bugge TH, Antalis TM: Membrane-anchored serine protease matriptase regulates epithelial barrier formation and permeability in the intestine. Proc Natl Acad Sci USA 2010;107:4200-4205.

-40 Belo AA, Sousa Mde O, Machado EL, Figueiredo AF: On human tissue kallikrein activity in urine of Brazilian White and Black primary hypertensive patients. Ethn Dis 2009; 19:265-270.

41 Margolis HS, Geller R, Pisano JJ, Sjoerdsma A: Altered urinary kallikrein excretion in human hypertension. Lancet 1971;ii:10631065

42 Olivieri O, Castagna A, Guarini P, Chiecchi L, Sabaini G, Pizzolo F, Corrocher R, Righetti PG: Urinary prostasin: a candidate marker of epithelial sodium channel activation in humans. Hypertension 2005;46:683-688.

$\checkmark 43$ Geller RG, Margolius HS, Pisano JJ, Keiser HR: Effects of mineralocorticoids, altered sodium intake, and adrenalectomy on urinary kallikrein in rats. Circ Res 1972;31:857861.

$>44$ Ergonul Z, Frindt G, Palmer LG: Regulation of maturation and processing of $\mathrm{ENaC}$ subunits in the rat kidney. Am J Physiol Renal Physiol 2006;291:F683-F693.

45 Frindt G, Ergonul Z, Palmer LG: Surface expression of epithelial $\mathrm{Na}$ channel protein in rat kidney. J Gen Physiol 2008;131:617-627.

46 Masilamani S, Kim GH, Mitchell C, Wade JB, Knepper MA: Aldosterone-mediated regulation of $\mathrm{ENaC} \alpha-, \beta$-, and $\gamma$-subunit proteins in rat kidney. J Clin Invest 1999; 104:R19-R23. 